\title{
Efektivitas Implementasi Pendekatan Scientific dengan Model Problem Based Learning dan Learning Cycle 5E
}

\author{
Trysa Gustya Manda ${ }^{1, *)}$, Marsigit $^{2)}$ \\ ${ }^{1)}$ Program Studi Pendidikan Matematika, FMIPA, Universitas Negeri Padang \\ ${ }^{2)}$ Prodi Pendidikan Matematika Jurusan Matematika, Universitas Negeri Yogyakarta \\ *trysagustya@ fmipa.unp.ac.id
}

\begin{abstract}
The purposes of this research are to describe and compare the effectiveness of the imple mentation of scientific approach using problem based learning and learning cycle 5E model viewed from achievement spiritual attitudes, social attitudes, knowledge, and skills of students on polyhedral topic in Junior High School Grade VIII. This research is quasi experiment using nonequivalent (pretest and post-test) group design. Population in this research are all of students grade VIII Junior High

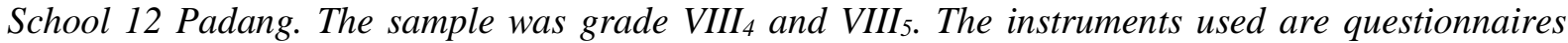
spiritual attitude and social attitude, knowledge and skill test. The results of the research are as follows the implementation of scientific approach with problem based learning and learning cycle 5E model is effective viewed from the achievement spiritual attitudes, social attitudes and knowledge of students, but not effective viewed from students skill, and there are no differences between the effectiveness of the implementation of scientific approach using problem based learning and learning cycle $5 E$ model.
\end{abstract}

Keywords :Scientific approach, Problem based learning, Learning cycle 5E, Ability

This is an open access article distributed under the Creative Commons 4.0 Attribution License, which permits unrestricted use, distribution, and reproduction in any medium, provided the original work is properly cited. @2021 by author

\section{PENDAHULUAN}

Perkembangan pendidikan sejalan dengan perkembangan kurikulum yang digunakan pada setiap jenjang pendidikan. Pelaksanaan pendidik an memiliki tujuan yang dibagi dalam tiga ranah pendidikan yaitu kognitif, afektif, dan psikomo tor. Hal ini juga berlaku untuk pembelajaran matematika. Tujuan pembelajaran matematika pada Kurikulum 2013 (Permendiknas No.58, 2014), menunjukkan bahwa pembelajaran mate matika tidak hanya difokuskan pada kemampuan kognitif siswa. Pembelajaran matematika juga bertujuan untuk mengembangkan aspek afektif siswa dalam aspek spiritual dan sosial.

Pembelajaran yang dilakukan saat ini ha rus sesuai dengan Kurikulum 2013. Kurikulum 2013 dikembangkan atas dasar teori pendidikan berdasarkan standar dan teori kurikulum berba sis kompetensi (Kemendikbud, 2014). Kuriku lum 2013 dirancang agar siswa dapat mengem bangkan kompetensi inti, yaitu kemampuan da lam bersikap, berpengetahuan, dan berketeram pilan. Kompetensi inti dirancang sesuai dengan tujuan pendidikan nasional yang terdiri dari kom petensi inti, yaitu sikap spiritual (KI 1), sikap so sial (KI 2), pengetahuan (KI3), dan keteram pilan (KI 4).
Sikap spiritual menurut Brelsford \& Maho ney (Luquis, 2012); Rossiter (Souza, 2009); Dehler \& Welsh (Choerudin, 2015); (Fathur rohman, 2013) merupakan proses membangun dan mempertahankan keyakinan yang meliputi kepercayaan, dan usaha yang berhubungan de ngan hal-hal yang bersifat ketuhanan atau ke giatan religius yang dideskripsikan melalui sikap patuh dalam melaksanakan ajaran agama, tole ran dan hidup dengan pemeluk agama lain.

Kompetensi sikap sosial dalam Kurikulum 2013 terdiri dari beberapa sikap yang harus di miliki siswa dalam pembelajaran. Sikap sosial yang dikembangkan yaitu teliti, rasa ingi tahu, dan menghargai. Teliti merupakan sikap untuk berhati-hati, mampu memeriksa kembali suatu hal yang dikerjakan dan tidak terburu-buru da lam menemukan hasil dari suatu permasalahan (Stevenson, 2006). Rasa ingin tahu menurut (Mc Elmeel, 2002); (Nowotny, 2008); (Rowson, 2012) merupakan emosi kognitif ketika adanya perbedaan dan memunculkan keinginan mem pelajari, menyelidiki dan mengetahui secara luas dan mendalam dengan menanyakan suatu per tanyaan. Menghargai merupakan sikap ramah, santun terhadap orang lain dan menghormati pen dapat orang lain (Fathurrohman, 2013); (Steven son, 2006). 
Kompetensi inti pengetahuan dalam Kuri kulum 2013 yang harus dimiliki oleh siswa ada lah memahami pengetahuan berupa fakta, kon sep, prinsip dan prosedur. Kompetensi inti kete rampilan yang dimaksud dalam Kurikulum 2013 meliputi: keterampilan mencoba, mengolah, menyaji, dan menalar (Kemendikbud, 2013). Un tuk ketercapaian aspek kompetensi inti, berbagai usaha telah dilakukan untuk mendukung pening katan kualitas pembelajaran matematika seperti penyempurnaan kurikulum, penataan guru, dan penambahan sarana dan prasarana dalam proses pembelajaran matematika. Penguatan untuk pro ses pembelajaran pada Kurikulum 2013 dilaku kan melalui pendekatan scientific (Kemendik bud, 2013). Proses pembelajaran dengan pende katan scientific terdiri atas lima pengalaman bela jar yaitu: (1) mengamati, (2) menanya, (3) me ngumpulkan informasi, (4) mengasosiasi, dan (5) mengkomunikasikan (Kemendikbud, 2013). Langkah-langkah pembelajaran dengan pende katan scientific meliputi: (1) mengamati, (2) me nanya, (3) mengumpulkan informasi, (4) menga sosiasi, (5) mengkomunikasikan, dan (6) mem bentuk jejaring (Hosnan, 2014).

Pendekatan scientific dapat diterapkan de ngan pembelajaran yang berbasis penyingkapan/ penelitian (Kemendikbud, 2013). Pendekatan pembelajaran berbasis pemecahan masalah da pat mengembangkan kemampuan siswa untuk menghasilkan karya yang kontekstual. Menurut Yunus pembelajaran dengan pendekatan scienti fic menuntut siswa untuk berpikir sistematis dan kritis dalam pemecahan masalah yang bersifat analisis (Usmadi, 2019). Salah satu model pem belajaran matematika yang menggunakan ba nyak masalah praktis adalah model Problem Based Learning (PBL). Salah satu model yang cocok untuk Kurikulum 2013 di SMP adalah model pembelajaran berbasis masalah (Marsigit, 2013). Proses pembelajaran dengan model PBL mengembangkan kemampuan siswa dalam me nyelesaikan masalah realistik yang dialami da lam kehidupan sehari-hari. Dalam pembelajaran dengan model PBL, guru bertindak sebagai fa silitator dan mediator. Siswa bekerja dengan ke lompok untuk menyelesaikan masalah yang kom pleks sehingga dapat membantu dalam mengem bangkan pengetahuan dalam pemecahan masa lah, berpikir, komunikasi, dan keterampilan pe nilaian diri. Tahapan dalam pembelajaran de ngan menggunakan model PBL terdiri dari: "(1) presenting the problem, (2) planning the investi gations, (3) conducting the investigations, (4) de monstrating learning, dan (5) reflecting and de briefing” (Arends \& Kilcher, 2010).

Proses pembelajaran menggunakan pende katan scientific dapat dikombinasikan dengan model PBL. Tahapan pembelajarannya yaitu pa da tahap mengamati berlangsung tahapan pre senting the problem, dimana siswa diarahkan pa da suatu masalah pada awal pembelajaran. Ke mudian pada tahap menanya dan planning the investigation, siswa diminta untuk bertanya ter kait masalah atau materi yang diberikan dan se hingga siswa dapat merencanakan penyelesaian masalah. Rasa ingin tahu siswa dikembangkan melalui kegiatan mengumpulkan informasi un tuk mengkontruksi pengetahuan dalam menye lesaikan masalah dengan cara diskusi kelompok. Pada tahap mengasosiasi, berlangsung tahap con ducting the investigations dimana siswa menye lesaikan masalah yang diberikan dengan teliti. Pada tahap mengkomunikasikan dan demon strating learning diharapkan siswa mampu me nyajikan hasil diskusi tentang penyelesaian masa lah pada LKS dan menerima pendapat siswa lainnya, hal ini dapat mengembangkan sikap menghargai siswa dalam berinteraksi. Tahapan terakhir dalam PBL yaitu reflecting and de briefing dilakukan oleh guru dan siswa.

Untuk membuktikan keefektifan pendekat an scientific dengan model PBL, perlu dilakukan penelitian yaitu membandingkannya dengan im plementasi pendekatan scientific dengan model lain. Dari hasil penelitian (Jun, et al., 2013), bah wa mengkombinasikan model PBL dan learning cycle 5E (LC 5E) dapat menjadi pilihan yang baik dalam belajar teori dan praktek. Maka salah satu model pembelajaran yang dapat dibanding kan dengan PBL adalah pembelajaran mengguna kan pendekatan scientific dengan model LC 5E.

Model pembelajaran LC 5E terdiri atas tahap engagement, exploration, explanation, ela boration, dan evaluation. Tahapan pembelajaran menggunakan pendekatan scientific dapat dikom binasikan dengan pembelajaran model LC 5E. Pembelajaran yang diterapkan diawali dengan tahap mengamati yang juga berlangsung tahap engagement dimana guru membangkitkan minat dan lebih memotivasi siswa untuk belajar de ngan menjelaskan hal yang berkaitan dengan ma teri yang akan dipelajari kemudian membantu siswa mampu mengkonstruk pengetahuannya sendiri dalam belajar. Kemudian siswa dikelom pokkan menjadi beberapa kelompok yang setiap 
kelompok heterogen dan membagikan LKS ke setiap kelompok. Pada tahap menanya siswa di minta untuk bertanya hal-hal yang berkaitan de ngan materi dan LKS yang akan dipelajari. Ta hap mengumpulkan informasi bertujuan untuk mengembangkan rasa ingin tahu siswa dengan mendiskusikan informasi yang diperlukan dalam mengerjakan LKS. Kemudian pada tahap menga sosiasi berlangsung tahapan exploration dimana siswa diminta untuk menyelesaikan kegiatan yang ada di LKS dengan teliti. Pada tahap meng komunikasi kan dan tahapan explanation, siswa mempresentasikan hasil diskusi, sehingga dapat mengembangkan sikap menghargai siswa. Pada tahap elaboration, siswa mengerjakan latihan un tuk menerapkan konsep yang diperoleh dari ha sil diskusi. Tahap terakhir yaitu evaluation, guru membimbing siswa untuk mengevaluasi hasil da ri pembelajaran yang dilakukam.

Berdasarkan uraian, pendekatan scientific dengan model PBL dan LC 5E dapat diterapkan dalam pembelajaran matematika, karena setiap tahap dalam masing-masing model dapat berlangsung pada pembelajaran dengan pende katan scientific. Pembelajaran dengan model LC 5E dan PBL dapat meningkatkan self-efficacy, berpikir kritis, sikap belajar, dan kepuasan bela jar (Jun, et al., 2013). Selain itu, pembelajaran dengan kedua model ini dapat membantu siswa dalam mengembangkan pengetahuan dan kete rampilannya sendiri. Penelitian ini bertujuan un tuk mendeskripsikan dan membandingkan ke efektifan implementasi pendekatan scientific de ngan model PBL dan LC 5E ditinjau dari keter capaian sikap spiritual, sikap sosial, pengetahu an dan keterampilan siswa pada materi bangun ruang sisi datar SMP 12 Padang Kelas VIII semester 2.

\section{METODE PENELITIAN}

Penelitian ini adalah penelitian eksperi men semu (quasi experiment) dengan desain pe nelitian nonequivalent (pre-test and post-test) group design, dimana variabel terikat diukur se belum dan setelah perlakuan diberikan (Mar czyk, DeMatteo \& Festinger, 2005). Populasi pe nelitian adalah seluruh siswa kelas VIII SMPN 12 Padang. Sampel penelitian yaitu kelas $\mathrm{VIII}_{4}$ dan kelas VIII 5 . Dari kedua kelas ditentukan se cara acak jenis pembelajaran yang diterapkan, di peroleh kelas $\mathrm{VIII}_{4}$ diterapkan pendekatan scien tific dengan model PBL dan kelas $\mathrm{VIII}_{5}$ diterap kan pendekatan scientific dengan model LC 5E.
Variabel bebas dalam penelitian ini adalah pem belajaran dengan implementasi pendekatan scien tific dengan model PBL dan model LC 5E, se dangkan variabel terikat adalah kompetensi si kap spiritual, sikap sosial, pengetahuan, dan ke terampilan.

Sebelum eksperimen dilakukan, diberikan pretest untuk melihat kondisi subjek berkenaan dengan variabel yang akan diukur sebelum per lakuan. Setelah perlakuan pada kedua kelompok eksperimen diberikan posttest dengan soal-soal yang sama atau sepadan. Teknik yang digunakan dalam penelitian ini adalah dengan tes dan non tes. Instrumen yang digunakan yaitu instrumen angket untuk mengukur sikap spiritual dan sikap sosial, tes pengetahuan berupa tes pilihan ganda, dan tes keterampilan berupa tes uraian.

Kisi-kisi dan indikator pencapaian kompe tensi sikap spiritual dan sikap sosial disusun ber dasarkan definisi konseptual dari sikap yang diu kur. Indikator sikap spiritual yaitu patuh dalam melaksanakan ajaran agama, toleran, dan hidup rukun dengan pemeluk agama lain. Indikator si kap sosial yang diukur berdasarkan definisi kon septual sikap teliti, rasa ingin tahu, dan menghar gai. Pernyataan disusun untuk setiap indikator terdiri dari pernyataan positif dan negatif. Alter natif jawaban yang diberikan terdiri dari jawab an untuk pernyataan positif dan pernyataan nega tif (Mardapi, 2012).

Kisi-kisi instrumen tes pengetahuan disu sun berdasarkan indikator dari kompetensi dasar dalam Kurikulum 2013. Indikator pencapaian instrumen tes pengetahuan yaitu KD 3.9 menjadi 16 indikator. Jumlah soal untuk KD 3.9 yaitu 16 soal. Indikator pencapaian untuk KD 3.11 dikem bangkan menjadi dua indikator. Jumlah soal un tuk KD 3.11 yaitu dua soal. Berarti untuk instrumen tes pengetahuan terdiri dari 18 soal. $\mathrm{Ki}$ si-kisi instrumen tes keterampilan disajikan pada Tabel 1.

Instrumen dalam penelitian ini divalidasi dengan validitas isi yaitu dengan meminta per timbangan ahli yaitu dua orang dosen pendidik an matematika. Reliabilitas instrumen tes penge tahuan dan keterampilan berhubungan dengan kepercayaan dan keajegan hasil uji coba instru men. Instrumen sikap spiritual, sikap sosial, dan tes pengetahuan diberikan skor 1 dan 0 , sedang kan untuk tes keterampilan penskoran dilakukan sesuai denan rubrik penskoran 4-1. Untuk instru men angket dan tes pengetahuan, rumus reliabili 
tas yang digunakan adalah rumus KR-20 berikut (Allen \& Yen, 1979).

$$
\rho_{x x^{\prime}}=r_{i}=\frac{N}{(N-1)}\left\{\frac{\sigma_{x}^{2}-\sum p_{i}\left(1-p_{i}\right)}{\sigma_{x}^{2}}\right\}
$$

Tabel 1. Kisi-kisi Tes Keterampilan

\begin{tabular}{|c|c|c|c|}
\hline \multirow{2}{*}{ KD } & \multirow{2}{*}{ Indikator } & \multicolumn{2}{|c|}{ No. Soal } \\
\hline & & Pre & Post \\
\hline $\begin{array}{l}4.9 \\
\text { Menyele } \\
\text { saikan } \\
\text { permasala }\end{array}$ & $\begin{array}{l}\text { 1. Menggunakan konsep } \\
\text { luas permukaan kubus } \\
\text { dalam menyelesaikan } \\
\text { permasalahan }\end{array}$ & $1 b$ & $2 b$ \\
\hline $\begin{array}{l}\text { han nyata } \\
\text { yang } \\
\text { terkait } \\
\text { penerapan }\end{array}$ & $\begin{array}{l}\text { 2. Menggunakan konsep } \\
\text { luas permukaan balok } \\
\text { dalam menyelesaikan } \\
\text { permasalahan }\end{array}$ & $1 b$ & $2 b$ \\
\hline $\begin{array}{l}\text { luas } \\
\text { permuka } \\
\text { an dan } \\
\text { volume }\end{array}$ & $\begin{array}{l}\text { 3. Menggunakan konsep } \\
\text { volume kubus dalam } \\
\text { menyelesaikan } \\
\text { permasalahan }\end{array}$ & $1 \mathrm{c}$ & $2 \mathrm{c}$ \\
\hline $\begin{array}{l}\text { kubus, } \\
\text { balok, } \\
\text { prisma, } \\
\text { dan limas }\end{array}$ & $\begin{array}{l}\text { 4. Menggunakan konsep } \\
\text { volume balok dalam } \\
\text { menyelesaikan } \\
\text { permasalahan }\end{array}$ & $1 \mathrm{c}$ & $2 c$ \\
\hline & $\begin{array}{l}\text { 5. Menggunakan konsep } \\
\text { luas permukaan } \\
\text { prisma dalam } \\
\text { menyelesaikan } \\
\text { masalah }\end{array}$ & 2 & $1 \mathrm{a}$ \\
\hline & $\begin{array}{l}\text { 6. Menggunakan konsep } \\
\text { luas permukaan limas } \\
\text { dalam menyelesaikan } \\
\text { permasalahan }\end{array}$ & 3 & $3 a$ \\
\hline & $\begin{array}{l}\text { 7. Menggunakan konsep } \\
\text { volume prisma dalam } \\
\text { menyelesaikan } \\
\text { permasalahan }\end{array}$ & $4 c$ & $1 b$ \\
\hline & $\begin{array}{l}\text { 8. Menggunakan konsep } \\
\text { volume limas dalam } \\
\text { menyelesaikan } \\
\text { permasalahan }\end{array}$ & $4 c$ & $3 b$ \\
\hline
\end{tabular}

Rumus reliabilitas yang digunakan untuk tes keterampilan adalah Cronbach Alpha.

$$
\sigma=\left[\frac{N}{N-1}\right]\left[\frac{\sigma_{X}^{2}-\sum_{i=1}^{N} \sigma_{y_{i}}^{2}}{\sigma_{X}^{2}}\right]
$$

Kriteria penerimaan reliabilitas adalah an tara 0,85 dan 0,95 , namun untuk standar kriteria penerimaan minimum reliabilitas 0,65 masih da pat diterima (Ebel \& Frisbie, 1991). Hasil perhi tungan reliabilitas untuk ujicoba instrumen ang ket sikap spiritual, sikap sosial, tes pengetahuan, dan keterampilan berturut-turut adalah 0,817, $0,802,0,753$, dan 0,811 . Berdasarkan hasil perhi tungan tersebut, maka angket sikap spiritual, si kap sosial, tes pengetahuan, dan keterampilan da pat dikatakan reliabel.
Analisis data dilakukan terhadap data pre test dan posttest. Data pretest dianalisis dengan menggunakan uji Manova untuk menentukan ke samaan vektor rerata dua kelompok dengan hipo tesis nol adalah rata-rata variabel ke-i kelompok pertama sama dengan rata-rata variabel ke-i ke lompok kedua. Hipotesis ditolak jika nilai proba bilitas kurang dari 0,05 . Uji multivariat kondisi awal dimaksudkan untuk melihat ada tidaknya perbedaan kemampuan awal siswa sebelum dibe rikan perlakuan. Hipotesis uji ini dapat duliskan sebagai berikut.

$$
\begin{aligned}
& H_{0}:\left(\begin{array}{c}
\mu_{P S P B L, S P} \\
\mu_{P S P B L, S S} \\
\mu_{P S P B L, P} \\
\mu_{P S P B L, K}
\end{array}\right)=\left(\begin{array}{c}
\mu_{P S C 5 E, S P} \\
\mu_{P S C 5 E, S S} \\
\mu_{P S C 5 E, P} \\
\mu_{P S C 5 E, K}
\end{array}\right) \\
& H_{1}:\left(\begin{array}{c}
\mu_{P S P B L, S P} \\
\mu_{P S P B L, S S} \\
\mu_{P S P B L, P} \\
\mu_{P S P B L, K}
\end{array}\right) \neq\left(\begin{array}{c}
\mu_{P S C 5 E, S P} \\
\mu_{P S C 5 E, S S} \\
\mu_{P S C 5 E, P} \\
\mu_{P S C 5 E, K}
\end{array}\right)
\end{aligned}
$$

Kriteria keputusan bahwa pengujian $\mathrm{H}_{0}$ di terima apabila uji SPSS (Hotelling's Trace) nilai signifikannya lebih dari 0,05 . Sedangkan kriteria keputusan kondisi akhir: $\mathrm{H}_{0}$ ditolak apabila nilai signifikansi kurang dari 0,05 . Uji hipotesis dila kukan untuk mengetahui keefektifan implemen tasi pendekatan scientific dengan model PBL dan LC 5E setelah perlakuan. Pembelajaran dika takan efektif ditentukan berdasarkan presentase pencapaian tujuan pembelajaran. Pencapaian tu juan pembelajaran dilihat dari kriteria ketuntas an minimal (KKM) dalam belajar matematika. Di SMP N 12 Padang siswa dikatakan tuntas di tinjau dari pengetahuan dan keterampilan mate matika jika mencapai KKM yaitu 80 .

Untuk kompetensi sikap spiritual dan si kap sosial data diperoleh dari skor setiap jawab an pada angket sikap spiritual dan sikap sosial. Penskoran angket sikap spiritual dan sikap sosial memiliki rentang antara 18 sampai dengan 90. Kriteria hasil pengukuran yang digunakan berda sarkan rata-rata ideal $\left(M_{i}=(18+90) / 2=54\right)$ dan standar deviasi ideal $\left(\mathrm{SD}_{\mathrm{i}}=(90-18) / 6=12\right)$ dengan kriteria berikut (Azwar, 2013).

Tabel 2. Kriteria Pengukuran Sikap Spiritual dan Sikap Sosial

\begin{tabular}{ccc}
\hline Interval & Skor (x) & Kriteria \\
\hline $\mathrm{Mi}+1,5 \mathrm{Sdi}<x \leq M i+3 \mathrm{Sdi}$ & $72<\mathrm{x} \leq 90$ & Sangat \\
$\mathrm{Mi}+0,5 \mathrm{Sdi}<x \leq M i+1,5 \mathrm{Sdi}$ & $60<\mathrm{x} \leq 72$ & Tinggi \\
$\mathrm{Mi}-0,5 \mathrm{Sdi}<x \leq M i+0,5 S d i$ & $48<\mathrm{x} \leq 60$ & Sedang \\
$\mathrm{Mi}-1,5 \mathrm{Sdi}<x \leq M i-0,5 S d i$ & $36<\mathrm{x} \leq 48$ & Rendah \\
$\mathrm{Mi}-3 \mathrm{Sdi} \leq \mathrm{x} \leq \mathrm{Mi}-1,5 \mathrm{Sdi}$ & $18 \leq \mathrm{x} \leq 36$ & Sangat \\
& & Rendah \\
\hline
\end{tabular}


Dalam penelitian ini pembelajaran matematika efektif ditinjau dari kompetensi sikap spiritual dan sosial jika rata-rata hasil pengukuran menca pai kriteria tinggi yaitu lebih dari 60 .

Untuk mengetahui keefektifan masing-ma sing pembelajaran, maka data posttest dianalisis dengan one smple t-test. Hipotesis implementasi pendekatan scientific dengan model PBL dan LC 5E efektif ditinjau dari sikap spiritual dan so sial siswa secara statistik dapat disimbolkan sebagai berikut.

$$
\begin{aligned}
& H_{0}: \mu_{S P, S S} \leq 60 \\
& H_{1}: \mu_{S P, S S}>60
\end{aligned}
$$

Hipotesis implementasi pendekatan scienti fic dengan model PBL dan LC 5E efektif ditin jau dari pengetahuan dan keterampilan siswa se cara statistik dapat disimbolkan sebagai berikut.

$$
\begin{aligned}
& H_{0}: \mu_{P, K} \leq 80 \\
& H_{1}: \mu_{P, K}>80
\end{aligned}
$$

Taraf signifikansi yang digunakan adalah $(\alpha)=0,05$. Dengan kriteria keputusannya adalah $\mathrm{H}_{\mathrm{o}}$ ditolak jika nilai sig. $<0,05$. Rumus yang di gunakan sebagai berikut.

$$
t=\frac{\bar{x}-\mu_{0}}{\frac{s}{\sqrt{n}}}
$$

Uji multivariat data posttest digunakan un tuk melihat ada tidaknya perbedaan keefektifan pembelajaran setelah diberikan perlakuan. Hipo tesis uji dituliskan sebagai berikut.

$$
\begin{aligned}
& H_{0}:\left(\begin{array}{c}
\mu_{P S P B L, S P} \\
\mu_{P S P B L, S S} \\
\mu_{P S P L L, P} \\
\mu_{P S P B L, K}
\end{array}\right)=\left(\begin{array}{c}
\mu_{P S C S E, S P} \\
\mu_{P S C S E, S S} \\
\mu_{P S C E E, P} \\
\mu_{P S C S E, K}
\end{array}\right) \\
& H_{1}:\left(\begin{array}{c}
\mu_{P S P B L, S P} \\
\mu_{P S P B L, S S} \\
\mu_{P S P B L, P} \\
\mu_{P S P B L, K}
\end{array}\right) \neq\left(\begin{array}{c}
\mu_{P S C S E, S P} \\
\mu_{P S C S E, S S} \\
\mu_{P S C S E, P} \\
\mu_{P S C S E, K}
\end{array}\right)
\end{aligned}
$$

Kriteria keputusan bahwa pengujian $\mathrm{H}_{0}$ di terima apabila uji SPSS (Hotelling's Trace) nilai signifikannya $>0,05$. Apabila terdapat perbeda an keefektifan implementasi pendekatan scienti fic dengan model PBL dan LC 5E, langkah selan jutnya adalah melihat mana yang lebih efektif di antara keduanya. Secara statistik, hipotesis-hipo tesis yang diuji sebagai berikut.

$$
\begin{aligned}
& H_{0}: \mu_{i 1} \leq \mu_{i 2} \\
& H_{1}: \mu_{i 1}>\mu_{i 2}
\end{aligned}
$$

Adapun statistik uji yang digunakan adalah uji univariat $t$ dengan menggunakan kriteria Benfe roni pada taraf signifikan 0,05 . Formula untuk

Volume 5| Nomor 2| November 2021|Page 118-127 statistik uji ini adalah sebagai berikut: (Stevens, 2009, p.147)

$$
t=\frac{\overline{y_{1}}-\overline{y_{2}}}{\sqrt{\frac{\left(n_{1}-1\right) S_{1}^{2}+\left(n_{2}-1\right) S_{2}^{2}}{n_{1}+n_{2}-2}\left(\frac{1}{n_{1}}+\frac{1}{n_{2}}\right)}}
$$

Adapun kriteria keputusannya adalah $\mathrm{H}_{\mathrm{o}}$ ditolak jika $t_{\text {hitung }}>t_{(0,05 ; n 1+n 2-2)}$ atau nilai signifikan 2tailed dibagi 2 lebih kecil dari 0,05.

\section{HASIL DAN PEMBAHASAN}

Hasil analisis pretest dan posttest sikap spiritual siswa pada kedua kelas sebelum dan se telah perlakuan dijelaskan pada Tabel 3 .

Tabel 3. Statistik Deskriptif dari Hasil Instrumen Angket Sikap Spiritual

\begin{tabular}{|c|c|c|c|c|}
\hline \multirow[t]{2}{*}{ Kriteria } & \multicolumn{2}{|c|}{$\begin{array}{c}\text { Kelas E1 } \\
\text { Scientific } \\
\text { dengan PBL }\end{array}$} & \multicolumn{2}{|c|}{$\begin{array}{c}\text { Kelas E2 } \\
\text { Scientific } \\
\text { dengan LC 5E }\end{array}$} \\
\hline & $\begin{array}{c}\text { Pre } \\
\%\end{array}$ & $\begin{array}{c}\text { Post } \\
\%\end{array}$ & $\begin{array}{c}\text { Pre } \\
\%\end{array}$ & $\begin{array}{c}\text { Post } \\
\%\end{array}$ \\
\hline Sangat tinggi & 83,3 & 90 & 90,3 & 93,5 \\
\hline Tinggi & 16,7 & 10 & 9,7 & 6,5 \\
\hline Sedang & 0 & 0 & 0 & 0 \\
\hline Rendah & 0 & 0 & 0 & 0 \\
\hline $\begin{array}{l}\text { Sangat } \\
\text { rendah }\end{array}$ & 0 & 0 & 0 & 0 \\
\hline Jumlah & 100 & 100 & 100 & 100 \\
\hline
\end{tabular}

\begin{tabular}{lcccc}
\hline \multirow{2}{*}{ Deskripsi } & \multicolumn{2}{c}{$\begin{array}{c}\text { Kelas E1 } \\
\text { Scientific } \\
\text { dengan PBL }\end{array}$} & \multicolumn{2}{c}{$\begin{array}{c}\text { Kelas E2 } \\
\text { Scientific } \\
\text { dengan LC 5E }\end{array}$} \\
\cline { 2 - 5 } & Pre & Post & Pre & Post \\
\hline Rata-rata & 81,07 & 83,03 & 80,45 & 81,45 \\
Standar Deviasi & 6,77 & 6,04 & 5,44 & 5,03 \\
Skor Maks Ideal & 90 & 90 & 90 & 90 \\
Skor Min Ideal & 18 & 18 & 18 & 18 \\
Skor Maks & 90 & 90 & 90 & 89 \\
Skor Min & 64 & 69 & 65 & 67 \\
\hline
\end{tabular}

Deskripsi jumlah siswa dan persentase untuk se tiap kriteria sikap spiritual siswa terhadap mate matika dihitung sesuai dengan skor yang diten tukan untuk setiap kriteria. Distribusi frekuensi dan persentase pretest dan posttest sikap spiri tual siswa dapat dilihat pada Tabel 4.

Tabel 4. Distribusi Frekuensi dan Persentase Sikap Spiritual Siswa

Hasil analisis pretest dan posttest sikap sosial sis wa untuk rata-rata, standar deviasi, skor maksi mal ideal, skor minimal ideal, skor maksimal, dan skor minimal disajikan pada Tabel 5.

Deskripsi jumlah siswa dan persentase un tuk setiap kriteria sikap sosial siswa terhadap ma tematika dihitung sesuai dengan skor yang diten tukan untuk setiap kriteria. 
Tabel 5. Statistik Deskriptif dari Hasil Instrumen Angket Sikap Sosial

\begin{tabular}{|c|c|c|c|c|}
\hline \multirow[t]{2}{*}{ Deskripsi } & \multicolumn{2}{|c|}{$\begin{array}{c}\text { Kelas E1 } \\
\text { Scientific } \\
\text { dengan PBL }\end{array}$} & \multicolumn{2}{|c|}{$\begin{array}{c}\text { Kelas E2 } \\
\text { Scientific } \\
\text { dengan LC } \\
5 \mathrm{E}\end{array}$} \\
\hline & Pre & Post & Pre & Post \\
\hline Rata-rata & 71,13 & 75,63 & 69,65 & 72,71 \\
\hline Standar Deviasi & 8,02 & 5,81 & 8,45 & 6,08 \\
\hline $\begin{array}{l}\text { Skor Maks } \\
\text { Ideal }\end{array}$ & 90 & 90 & 90 & 90 \\
\hline Skor Min Ideal & 18 & 18 & 18 & 18 \\
\hline Skor Maks & 84 & 89 & 87 & 84 \\
\hline Skor Min & 52 & 65 & 51 & 61 \\
\hline
\end{tabular}

Distribusi frekuensi dan persentase pretest dan posttest sikap sosial siswa terdapat pada Tabel 6.

Tabel 6. Distribusi Frekuensi dan Persentase Sikap Sosial Siswa

\begin{tabular}{ccccc}
\hline & \multicolumn{2}{c}{$\begin{array}{c}\text { Kelas E1 } \\
\text { Scientific }\end{array}$} & \multicolumn{2}{c}{ Kelas E2 } \\
Scientific \\
Kriteria & dengan PBL & \multicolumn{2}{c}{ dengan LC 5E } \\
& Pre & Post & Pre & Post \\
& $\%$ & $\%$ & $\%$ & $\%$ \\
\hline Sangat tinggi & 40 & 73,3 & 38,7 & 64,5 \\
Tinggi & 53,3 & 26,7 & 48,3 & 35,5 \\
Sedang & 6,7 & 0 & 12,9 & 0 \\
Rendah & 0 & 0 & 0 & 0 \\
Sangat & 0 & 0 & 0 & 0 \\
rendah & & 100 & 100 & 100 \\
Jumlah & 100 & 100
\end{tabular}

Hasil analisis pretest dan posttest pengetahuan siswa untuk rata-rata, standar deviasi, skor mak simal ideal, skor minimal ideal, skor maksimal, dan skor minimal dapat dilihat seperti Tabel 7.

Tabel 7. Statistik Deskriptif dari Hasil Instrumen Tes Pengetahuan

\begin{tabular}{|c|c|c|c|c|}
\hline \multirow[t]{2}{*}{ Deskripsi } & \multicolumn{2}{|c|}{$\begin{array}{c}\text { Kelas E1 } \\
\text { Scientific } \\
\text { dengan PBL }\end{array}$} & \multicolumn{2}{|c|}{$\begin{array}{c}\text { Kelas E2 } \\
\text { Scientific } \\
\text { dengan LC } \\
5 \mathrm{E}\end{array}$} \\
\hline & Pre & Post & Pre & Post \\
\hline Rata-ra & & & & 85,48 \\
\hline Standa & $1 /$, & 12, & 14,55 & 10,31 \\
\hline $\begin{array}{l}\text { Skor Maks } \\
\text { Ideal }\end{array}$ & 100 & 100 & 100 & 100 \\
\hline & 0 & O & 0 & 0 \\
\hline & & & 8,89 & 100 \\
\hline Skor Min & 27,78 & 61,11 & 33,33 & 66,67 \\
\hline
\end{tabular}

Hasil analisis pretest dan posttest keterampilan siswa untuk rata-rata, standar deviasi, skor mak simal ideal, skor minimal ideal, skor maksimal, dan skor minimal pada kedua kelas seperti pada Tabel 8.

Tabel 8. Statistik Deskriptif dari Hasil Instrumen Tes Keterampilan

\begin{tabular}{lcccc}
\hline & \multicolumn{2}{c}{$\begin{array}{c}\text { Kelas E1 } \\
\text { Scientific }\end{array}$} & \multicolumn{2}{c}{$\begin{array}{c}\text { Kelas E2 } \\
\text { Scientific } \\
\text { dengan LC }\end{array}$} \\
& dengan PBL & \multicolumn{2}{c}{ 5E } \\
& Pre & Post & Pre & Post \\
\hline Rata-rata & 36,09 & 81,31 & 30,67 & 73.16 \\
Standar Deviasi & 24,29 & 12,64 & 25,45 & 11,69 \\
Skor Maks & 100 & 100 & 100 & 100 \\
Ideal & 0 & 0 & 0 & 0 \\
Skor Min Ideal & 0 & 100 & 71,43 & 100 \\
Skor Maks & 71,43 & 0 & 0 \\
Skor Min & 0 & 60,7 & 0 & 50 \\
\hline
\end{tabular}

Uji hipotesis dilakukan untuk mengambil keputusan berdasarkan data yang diperoleh.

\section{Hasil Analisis Data Sebelum Perlakuan}

Sebelum uji hipotesis dilakukan terlebih dahulu dilakukan uji asumsi. Uji normalitas dila kukan dengan uji Kolmogorov-Smirnov. Berda sarkan hasil output untuk pretest sikap spiritual, sosial, pengetahuan, dan keterampilan kelas eks perimen dengan implementasi pendekatan scien tific dengan model PBL secara berturut-turut ni lai signifikansinya adalah $0,488,0,919,0,578$, dan 0,191 . Hasil analisis untuk pretest sikap spi ritual, sosial, pengetahuan, dan keterampilan ke las eksperimen dengan implementasi pendekatan scientific dengan model LC 5E berturut-turut ni lai signifikansinya adalah $0,647,0,871,0,674$, dan 0,401. Hasil analisis data ini menunjukkan bahwa nilai probabilitas lebih dari 0,05 , maka da ta pretest pada kedua kelas eksperimen berdis tribusi normal sehingga asumsi normalitas data terpenuhi.

Uji homogenitas dilakukan untuk data pre test pada kedua kelas eksperimen menggunakan uji Box's M. Berdasarkan hasil output SPSS di peroleh nilai Box's M untuk data sebelum perla kuan adalah 11,110 dengan signifikansi 0,415. Dari hasil tersebut karena 0,415>0,05 maka va rians-kovarians dari data pretest di kedua kelas eksperimen sama atau homogen. Hal ini berarti bahwa populasi penelitian mempunyai varianskovarians yang homogen.

Setelah uji prasyarat terpenuhi, untuk me ngetahui apakah terdapat perbedaan rerata antara kedua kelas eksperimen, maka dilakukan uji mul 
tivariat (MANOVA). Berdasarkan hasil output SPSS diketahui bahwa nilai $F$ yaitu $1,439^{\mathrm{b}}$ dan nilai signifikan 0,233 . Hasil dari taraf signifikan si tersebut lebih besar dari 0,05 , sehingga $\mathrm{H}_{0}$ diterima artinya tidak terdapat perbedaan rerata antara kedua kelas eksperimen ditinjau dari ke tercapaian kompetensi sikap spiritual, sosial, pe ngetahuan, dan keterampilan siswa.

\section{Hasil Analisis Data Setelah Perlakuan}

Analisis tentang keefektifan bertujuan un tuk mengetahui apakah pendekatan scientific de ngan model PBL dan LC 5E efektif ditinjau dari ketercapaian sikap spiritual, sosial, pengetahuan, dan keterampilan matematika siswa. Pada uji ini digunakan uji one sample t-test dengan taraf sig nifikansi 0,05 . Hasil uji one sample t-test untuk masing-masing data posttest kedua kelas ekspe rimen seperti pada Tabel 9 .

Tabel 9. Hasil Uji One Sample t-Test

\begin{tabular}{|c|c|c|c|c|}
\hline $\begin{array}{c}\text { Kelom } \\
\text { pok }\end{array}$ & Variabel & $\mathbf{t}$ & df & Sig. \\
\hline \multirow{4}{*}{$\begin{array}{l}\text { Scien } \\
\text { tific de } \\
\text { ngan } \\
\text { PBL }\end{array}$} & $\begin{array}{c}\text { Sikap } \\
\text { Spiritual }\end{array}$ & 20,897 & 29 & 0,000 \\
\hline & Sikap Sosial & 14,738 & 29 & 0,000 \\
\hline & Pengetahuan & 3,214 & 29 & 0,0015 \\
\hline & Keterampilan & 0,568 & 29 & 0,2875 \\
\hline \multirow{4}{*}{$\begin{array}{c}\text { Scien } \\
\text { tific de } \\
\text { ngan } \\
\text { LC 5E }\end{array}$} & $\begin{array}{c}\text { Sikap } \\
\text { Spiritual }\end{array}$ & 23,766 & 30 & 0,000 \\
\hline & Sikap Sosial & 11,642 & 30 & 0,000 \\
\hline & Pengetahuan & 2,961 & 30 & 0,003 \\
\hline & Keterampilan & $-3,257$ & 30 & 0,4993 \\
\hline
\end{tabular}

Hasil uji menunjukkan bahwa pendekatan scien tific dengan model PBL dan LC 5E efektif ditin jau dari ketercapaian kompetensi sikap spiritual, sosial, dan pengetahuan matematika siswa, na mun tidak efektif ditinjau dari keterampilan ma tematika siswa.

Sebelum dilakukan uji hipotesis dilakukan uji asumsi terhadap data-data posttest. Berdasar kan hasil output untuk posttest sikap spiritual, so sial, pengetahuan, dan keterampilan kelas ekspe rimen dengan pendekatan scientific dengan mo del PBL secara berturut-turut nilai signifikan sinya adalah $0,083,0,871,0,263$, dan 0,515 . Ha sil analisis untuk posttest sikap spiritual, sosial, pengetahuan, dan keterampilan pada kelas de ngan pendekatan scientific dengan model LC 5E berturut-turut nilai signifikansinya adalah 0,687 , $0,373,0,412$, dan 0,514 . Hasil analisis data ini menunjukkan nilai probabilitas lebih dari 0,05 , sehingga data posttest pada kedua kelas ekspe rimen berdistribusi normal.
Hasil uji homogenitas yang dilakukan ada lah data posttest dan dianalisis menggunakan uji Box's $M$ adalah 13,148 dengan signifikansinya 0,273 . Karena $0,273>0,05$ maka varians-kova rians dari data posttest di kedua kelas ekspe rimen sama atau homogen. Hal ini berarti bahwa populasi penelitian mempunyai varians-kovari ans yang sama atau homogen.

Analisis selanjutnya adalah menguji perbe daan keefektifan pendekatan scientific dengan mo del PBL dan LC 5E ditinjau dari ketercapai an sikap spiritual, sosial, pengetahuan, dan ke terampilan. Untuk mengetahui apakah terdapat perbedaan mean antara kedua pembelajaran, ma ka dilakukan uji statistik MANOVA. Hasil anali sis data menggunakan kriteria Hotelling's Trace diperoleh $\mathrm{F}$ hitung sebesar $2,470^{\mathrm{b}}$ dengan signifi kansi 0,055. Dengan demikian dapat disimpul kan $\mathrm{H}_{0}$ diterima atau tidak terdapat perbedaan mean antara pendekatan scientific dengan model PBL dan pendekatan scientific dengan model LC $5 \mathrm{E}$.

\section{Keefektifan Pendekatan Scientific dengan Model Problem Based Learning}

Berdasarkan hasil uji hipotesis, diperoleh nilai pada uji one sample t-test untuk keefektifan pendekatan scientific dengan model PBL ditin jau dari sikap spiritual sebesar 20,897 dengan signifikansi $0,000<0,05$. Berdasarkan hasil ra tarata kelas untuk posttest sikap spiritual di kelas eksperimen 1 adalah 83,03 lebih besar dari 60 . Dari hasil tersebut dapat disimpulkan $\mathrm{H}_{0}$ dito lak, artinya pendekatan scientific dengan model PBL efektif ditinjau dari ketercapaian kompeten si sikap spiritual siswa.

Hasil uji hipotesis juga menunjukkan ke efektifan pendekatan scientific dengan model PBL ditinjau dari sikap sosial siswa. Berdasar kan hasil uji tersebut diperoleh bahwa pendekat an scientific dengan model PBL ditinjau dari si kap sosial sebesar 14,738 dengan signifikansi $0,000<0,05$. Berdasarkan hasil rata-rata kelas untuk posttest sikap sosial di kelas eksperimen 1 adalah 75,63 lebih besar dari 60. Dari hasil terse but dapat disimpulkan $\mathrm{H}_{0}$ ditolak artinya pem belajaran menggunakan pendekatan scientific de ngan model PBL ditinjau dari sikap sosial siswa.

Berdasarkan hasil uji hipotesis diperoleh nilai untuk keefektifan pendekatan scientific de ngan model PBL ditinjau dari pengetahuan sebe sar 3,214 dengan signifikansi $0,0015<0,05$. Ber dasarkan hasil rata-rata kelas untuk posttest pe ngetahuan di kelas eksperimen 1 adalah 87,22 le 
bih besar dari 80. Dari hasil tersebut dapat disim pulkan $\mathrm{H}_{0}$ ditolak, artinya pembelajaran menggu nakan pendekatan scientific dengan model PBL efektif ditinjau dari ketercapaian kompetensi pe ngetahuan siswa. Hal ini sejalan dengan pen dapat Hoffman \& Ritchie (Sungur \& Tekkaya, 2006) bahwa pembelajaran dengan mengguna kan model PBL dapat meningkatkan pengetahu an siswa.

Hasil uji hipotesis menunjukkan keefek tifan pendekatan scientific dengan model PBL yang ditinjau dari keterampilan matematika siswa adalah 0,568 dengan taraf signifikansi 0,2875 . Taraf signifikansi tersebut lebih besar dari 0,05 sehingga dapat disimpulkan $\mathrm{H}_{0}$ diteri ma, artinya pembelajaran menggunakan pende katan scientific dengan model PBL tidak efektif jika ditinjau dari keterampilan siswa. Hal ini ti dak sesuai dengan yang diharapkan bahwa da lam pembelajarannya dapat meningkatkan kete rampilan siswa dalam menyelesaikan masalah. Namun berdasarkan hasil rata-rata kelas untuk posttest pengetahuan di kelas eksperimen 1 ada lah 81,31 lebih besar 80 sehingga dapat dikata kan pendekatan scientific dengan model PBL efektif ditinjau dari keterampilan. Menurut Hoff man \& Ritchie (Sungur \& Tekkaya, 2006) bah wa pembelajaran dengan menggunakan PBL da pat meningkatkan keterampilan siswa

\section{Keefektifan Pendekatan Scientific dengan Model Learning Cycle 5E}

Berdasarkan hasil uji hipotesis, diperoleh nilai untuk keefektifan pendekatan scientific de ngan model LC 5E ditinjau dari sikap spiritual sebesar 23,766 dengan signifikansi 0,000 <0,05. Berdasarkan hasil rata-rata kelas untuk posttest sikap spiritual di kelas eksperimen 2 adalah 81,45 lebih besar dari 60. Dari hasil tersebut da pat disimpulkan $\mathrm{H}_{0}$ ditolak, artinya pembelajar an menggunakan pendekatan scientific dengan model LC 5E efektif ditinjau dari ketercapaian kompetensi sikap spiritual siswa.

Pada hasil uji hipotesis, diperoleh nilai un tuk keefektifan pendekatan scientific dengan mo del LC 5E ditinjau dari sikap sosial sebesar 11,642 dengan signifikansi $0,000<0,05$. Berda sarkan hasil rata-rata kelas untuk posttest sikap sosial di kelas eksperimen 2 adalah 72,71 lebih besar dari 60. Dari hasil tersebut dapat disimpul kan $\mathrm{H}_{0}$ ditolak, artinya pembelajaran mengguna kan pendekatan scientific dengan model LC 5E efektif ditinjau dari ketercapaian kompetensi si kap sosial siswa.

Volume 5| Nomor 2| November 2021|Page 118-127
Melihat hasil uji hipotesis, diperoleh nilai untuk keefektifan pendekatan scientific dengan model LC 5E ditinjau dari ketercapaian penge tahuan matematika siswa adalah 2,961 dengan signifikansi $0,003<0,05$. Berdasarkan hasil ratarata kelas untuk posttest pengetahuan di kelas eksperimen 2 adalah 85,48 lebih besar dari 80 . Dari hasil tersebut dapat disimpulkan $\mathrm{H}_{0}$ ditolak, artinya pembelajaran menggunakan pendekatan scientific dengan model LC 5E efektif ditinjau dari ketercapaian kompetensi pengetahuan sis wa. Pembelajaran dengan model 5E memiliki efek yang positif terhadap proses kognitif siswa (Ulas, Sevim, \& Tan, 2011). Dari hasil peneli tian (Tuna \& Kacar, 2013) diketahui bahwa pem belajaran dengan menggunakan model LC 5E da pat meningkatkan hasil belajar dan pengetahuan trigonometri siswa. Berdasarkan hal tersebut ma ka pembelajaran dengan model LC 5E efektif di tinjau dari pengetahuan siswa.

Berdasarkan hasil uji hipotesis, diperoleh nilai untuk keefektifan pendekatan scientific de ngan model learning cycle $5 E$ ditinjau dari kete rampilan siswa adalah $-3,257$ dengan signifikan si $0,4993>0,05$. Dari hasil tersebut dapat disim pulkan $\mathrm{H}_{0}$ diterima, artinya pembelajaran meng gunakan pendekatan scientific dengan model LC 5E tidak efektif ditinjau dari ketercapaian kom petensi keterampilan matematika siswa. Hal ini juga terlihat pada hasil rata-rata kelas untuk post test keterampilan di kelas eksperimen 2 yang di peroleh yaitu 73,16 lebih kecil dari 80 maka im plementasi pendekatan scientific dengan model LC 5E tidak efektif ditinjau dari keterampilan siswa. Keterampilan siswa dikembangkan mela lui tahapan-tahapan kegiatan dalam menyelesai kan LKS dan dalam menyelesaikan masalah nya ta. Kegiatan yang dilakukan diharapkan sejalan dengan hasil analisis dan kajian teori bahwa pem belajaran menggunakan pendekatan scientific de ngan model LC 5E diharapkan efektif ditinjau dari ketercapaian kompetensi keterampilan.

\section{Perbedaan Keefektifan Pendekatan Scientific dengan Model Problem Based Learning dan Model Learning Cycle 5E}

Jika diperhatikan uji hipotesis yang dilaku kan diperoleh $\mathrm{F}$ hitung $2,470^{\mathrm{b}}$ dengan signifikan si 0,055 . Dari hasil yang diperoleh, disimpulkan bahwa $\mathrm{H}_{0}$ diterima artinya tidak terdapat perbe daan keefektifan antara pendekatan scientific de ngan model PBL dan pendekatan scientific de ngan model LC 5E ditinjau dari ketercapaian sikap spiritual, sosial, pengetahuan, dan keteram 
pilan siswa pada materi bangun ruang sisi datar SMP Kelas VIII. Berdasarkan proses pelaksana an pembelajaran, terdapat perbedaan dalam pro ses pembelajaran yang dilakukan seperti yang te lah dijabarkan pada kajian pustaka sebelumnya. Perbedaannya yaitu dalam implementasi pende katan scientific dengan model PBL siswa diajar kan dengan berbasis masalah. Siswa diarahkan pada masalah nyata yang berkaitan dengan mate ri yang diajarkan. Dari masalah yang diberikan siswa dituntun untuk dapat menemukan sendiri rumus yang digunakan untuk menyelesaikan ma salah yang diberikan. Siswa diminta untuk me nyelesaikan masalah tersebut berdasarkan caracara yang mereka tentukan dan temukan sendiri ketika menyelesaikan LKS. Sebagai latihan, sis wa diharapkan mampu menyelesaikan masalahmasalah nyata yang berkaitan dengan materi yang diajarkan. Sedangkan implementasi pende katan scientific dengan model LC 5E, siswa di berikan penjelasan terlebih dahulu mengenai ma teri yang akan diajarkan, kemudian siswa di minta untuk menemukan kembali rumus-rumus yang berkaitan dengan materi yang diajarkan me lalui kegiatan di LKS. Hasil yang diperoleh sis wa pada kegiatan sebelumnya digunakan untuk menyelesaikan masalah nyata sebagai latihan yang berkaitan dengan materi yang diajarkan.

Implementasi pendekatan scientific dilaku kan dengan perilaku jujur, disiplin, tanggung ja wab, peduli, santun, dan sikap lainnya. Hal ini menunjukkan bahwa sikap juga merupakan solu si dari berbagai permasalahan dalam berinteraksi secara efektif dengan lingkungan sosial dan ling kungan alam. Model pembelajaran PBL merupa kan pembelajaran yang menjadikan masalah se bagai media untuk belajar. Proses penyelesaian masalah tersebut dapat membantu siswa me ngembangkan keterampilan menyelesaikan masa lah, berpikir kritis, hingga terbentuknya pengeta huan baru. Dan model pembelajaran LC 5E me rupakan pembelajaran yang dapat meningkatkan motivasi siswa untuk belajar karena siswa dili batkan secara aktif dalam pembelajaran sehing ga hal tersebut dapat meningkatkan efektifitas pembelajaran. Berdasarkan hal tersebut, maka dapat disimpulkan bahwa tidak terdapat perbeda an keefektifan antara implementasi pendekatan scientific dengan model PBL dan implementasi pendekatan scientific dengan model LC 5E.

\section{KESIMPULAN}

Kesimpulan yang diperoleh dari hasil pe nelitian ini adalah implementasi pendekatan scientific dengan model PBL dan LC 5E efektif ditinjau dari ketercapaian sikap spiritual, sikap sosial, dan pengetahuan, namun tidak efektif ji ka ditinjau dari ketercapaian keterampilan siswa pada materi bangun ruang sisi datar SMP Kelas VIII Semester 2, dan tidak terdapat perbedaan keefektifan implementasi pendekatan scientific dengan model PBL dan LC 5E ditinjau dari ke tercapaian sikap spiritual, sikap sosial, pengeta huan dan keterampilan siswa pada materi ba ngun ruang sisi datar pada tingkat SMP Kelas VIII Semester 2.

\section{DAFTAR PUSTAKA}

Allen, M. J. \& Wendy M. Yen. (1979). Intro duction to Measurement Theory. Belmont, California: Wadsworth, Inc.

Arends, R.I., \& Kilcher, A. (2010). Teaching for Student Learning Becoming an Accomplish Ed Teacher. Madison Avenue, New York: Routledge.

Azwar, S. (2013). Tes prestasi. Fungsi dan Pengembangan Pengukuran Prestasi Bela Jar. Yogyakarta: Pustaka Pelajar.

Choerudin, A. (Agustus 2015). The Role of Spirituality An Employee to Organi zations Business: A Review. International Journal of Information, Business and Management, 7 (3), 191-199.

Ebel, R.L., \& Frisbie, D.A. (1991). Essentials of Educational Measurement ( $5^{\text {th }}$ ed). Engle wood Cliffs, NJ: Prentice-Hall, Inc.

Fathurrohman, P., Suryana, AA., \& Fatriany, F. (2013). Pengembangan Pendidikan Karak ter. Bandung: Refika Aditama.

Hosnan, M. (2014). Pendekatan Saintifik dan Kontekstual dalam Pembelajaran Abad 21 Kunci Sukses Implementasi Kurikulum 2013. Jakarta: Ghalia Indonesia.

Jun, W. H., et al. (2013). Use of the 5e Learning Cycle Model Combined with Problem-Ba sed Learning For A Fundamentals of Nursing Course. Journal of Nursing Education, 52 (12), 681-689.

Kemendikbud. (2013). Peraturan Menteri Pendi dkan dan Kebudayaan Nomor 81 A Tahun 2013 Tentang Implementasi Kurikulum 2013.

Kemendikbud. (2014). Peraturan Menteri Pen didikan dan Kebudayaan Nomor 58 Tahun 
2014 Tentang Kerangka Dasar dan Struktur Kurikulum Sekolah Mene ngah.

Luquis, R.R., Brelsford, G.M., \& Rojas-guyler, L. (September 2012). Religiosity, Spiri tuality, Sexual Attitudes, and Sexual Beha Viors Among College Students. Journal of Religion and Health, 51 (3), 601-614.

Manda, T. G. (2012). Pemahaman Konsep Luas dan Volume Bangun Ruang Sisi Datar Sis wa Melalui Penggunaan Model Learning Cycle 5E Disertai Peta Konsep. Jurnal Pen didikan Matematika, 1(1).

Marczyk, G., DeMatteo, D., \& Festinger, D. (2005). Essentials of Research Design and Methodology. Hoboken, New Jersey: John Wiley \& Sons, Inc.

Mardapi, D. (2012). Pengukuran Penilaian \& Evaluasi Pendidikan. Yogyakarta: Nuha Medika.

McElmeel, S.L. (2002). Character Education: a Book Guide for Teachers, Librarians, and Parents. Greenwood Village, Colorado: Greenwood Publishing Group, Inc.

Nowotny, H. (2008). Insatiable Curiosity. Inno vation in a Fragile Future. (Terjemah an Mitch Cohen). Cambridge, Massachusett s: The MIT Press. (Buku asli diterbitkan tahun 2005).

Rowson, J. (2012). The Power of Curiosity, How Linking Inquisitiveness to Innovation Could Help to Address Our Energy Challenges. London: RSA Social Brain Centre.

Souza, M., Durka, G., Engebretson, K., et al. (2009). International Handbook of The
Religious, Moral, and Spiritual Dimen sions in Education: Part One, 183-200. Dor drecht, Netherlands: Springer.

Stevens, J. (2009). Applied Multivariate Statis tics for The Social Sciences. Madison Ave nue, New York: Rouletdge.

Stevenson, N. (2006). Young Person's Charac ter Education Handbook. Otis Avenue, India na polis: JIST Publishing, Inc.

Sungur, S. \& Tekkaya, C. (Juni 2006). Effects of Problem Based Learning and Traditional In Struction on Self-Regulated Learning. Journal of Education Research, 99 (5), 307-317.

Tuna, A. \& Kacar, A. (Januari 2013). The Effect of 5E Learning Cycle Model in Teaching Trigonometry on Students' Academic Achievement and The Permanence of Their Knowledge. International Journal on New Trends in Education and Their Implications, 4 (1), 73-87.

Ulas, A.H., Sevim, O., \& Tan, E. (2011). The Effect of Worksheets Based Upon 5e Learning Cycle Model on Student Success in Teaching of Adjectives as Grammatical Components. Procedia: Social and Behavioral Science, 31(2012), 391-398.

Usmadi, U., \& Ergusni, E. (2019). Penerapan Strategi Flipped Classroom dengan Pende katan Scientific dalam Pembelajaran Ma tematika pada Kelas XI SMKN 2 Padang Panjang. Jurnal Eksakta Pendidikan (JEP), 3 (2), 192-199. 